\title{
GASTRIC POLYPS: a retrospective analysis of 26,000 digestive endoscopies
}

\author{
Drausio Jefferson MORAIS ${ }^{1}$, Ademar YAMANAKA ${ }^{1}$, \\ José Murilo Robilotta ZEITUNE${ }^{1}$ and Nelson Adami ANDREOLLO²
}

\begin{abstract}
Background - Gastric polyps are small gastric lesions, asymptomatic in most cases and are generally discovered inadvertently during upper digestive endoscopy. Aim - To retrospectively review the characteristics and frequency of gastric polyps, derived from the gastric mucosal epithelium in a large series of endoscopies. Methods - One hundred and fifty three patients in a series of 26,000 consecutive upper digestive endoscopies done over a 5-year period, being that each patient had only one examination were analyzed and their histological and Yamada classification, as well as their location, size, histopathological findings and treatment studied. All patients had at least one gastric polyp, as confirmed by histological examination. Results - The polyps were classified as hyperplastic, adenomatous and fundic gland polyps. The most of them measure less than $1 \mathrm{~cm}$ (hyperplastic polyps - 60,5\%; adenomatous polyps - 73,6\%; fundic gland polyps - 72\%). Hyperplastic polyps were the most frequent and accounted for $71.3 \%$ of the cases, whereas fundic gland polyps accounted for $16.3 \%$ and adenomatous polyps for $12.4 \%$. Hyperplastic and adenomatous polyps were primarily single, whereas fundic gland polyps tended to be multiple. A carcinoma was detected in one hyperplastic polyp $(0.9 \%)$ and in two adenomatous polyps $(10.5 \%)$. High grade dysplastic foci were found in four adenomatous polyps (21\%). Conclusions - The digestive endoscopy is the safest and efficient method for the diagnosis of the gastric polyps, that in most of the patients does not show characteristic symptoms. The histopathological definition is not possible to the endoscopic glance being needed the pathologist's aid, once the conduct to be adopted will depend on the result of the biopsy.
\end{abstract}

HEADINGS - Stomach diseases. Polyps, surgery. Endoscopy, gastrointestinal.

\section{INTRODUCTION}

With the advent of modern techniques for digestive endoscopy, gastric polyps are now diagnosed more frequently, and can be studied using the material obtained by biopsy or polypectomy. Before the introduction of digestive endoscopy, the diagnosis of gastric polyps was based on x-ray examination, and the treatment involved surgery. Heinz, in 1911, was the first to observe gastric polyps by radiology, and the first endoscopic diagnosis was done by Schendler in $1922^{(10,16)}$.

In this study we analyzed the gastric polyps of 153 patients in a series of 26,000 consecutive endoscopies done over 5 years, being that each patient had only one examination. The features of the polyps examined included their location, diameter, morphological alterations and histological classification.

\section{METHODS}

The patients were analysed as the age, sex, gender and ethnic group, and the polyps as the location, size, Yamada's classification and histopathological findings.
Gastric polyps were diagnosed in 153 patients over a 5 -year period. All patients had at least one gastric polyp, as confirmed by histological examination. Endoscopy reports were consulted for data on polyp appearance, size, location, management and histopathological analysis. The polyps were classified as hyperplastic (HP), adenomatous (AP) and fundic gland polyps (FGP), based on the World Health Organization classification $^{(13)}$.

After fixation in $10 \%$ formalin, the specimens were embedded in paraffin and serial sections were stained with hematoxylin and eosin, and other stains, as required.

\section{RESULTS}

\section{Demographic information}

Ninety patients $(58.8 \%)$ were men and $63(41.2 \%)$ were women. Seventeen patients (11.1\%) were black and $136(88.9 \%)$ white. The median age was 64 years (range: 20-88; Table 1).

${ }_{1}^{1}$ Division of Gastroenterology: ${ }^{2}$ Department Surgery, Gastrocenter, UNICAMP Medical School, State University of Campinas, SP, Brasi .

Correspondence: Dr. Drausio Jefferson de Morais - Rua Julio Cesar, 210 - Centro - 13250-090 - Itatiba, SP, Brazil. E-mail: drausiomorais@yahoo.com.br 
TABLE 1. Relationship between polyp type, age and gender

\begin{tabular}{lcccc}
\hline \multirow{2}{*}{ Polyp type } & \multicolumn{4}{c}{ Patients } \\
\cline { 2 - 5 } & $\mathbf{n}$ & Age range $(\mathbf{Y})$ & Male & Female \\
\hline Hyperplastic & 109 & $20-88$ & 68 & 41 \\
Fundic gland & 25 & $30-78$ & 15 & 10 \\
Adenomatous & 19 & $32-75$ & 11 & 8 \\
\hline
\end{tabular}

\section{Histological classification of polyps}

The most frequent polyp types were hyperplastic $(n=109)$, fundic gland $(\mathrm{n}=25)$ and adenomatous $(\mathrm{n}=19)$ polyps. All patients with multiple polyps had only a single histological type.

\section{Location}

The location of the polyps was based on endoscopic findings, and the gastric areas were divided into antrum, body and fundus. Esophagogastric junction polyps were not found (Table 2).

TABLE 2. Relationship between polyp type and anatomical site. The values indicate the number of cases

\begin{tabular}{lcccc}
\hline Polyp type & Antrum & Body & Fundus & Anastomosis \\
\hline Hyperplastic & 47 & 39 & 13 & 10 \\
Adenomatous & 10 & 4 & 3 & 2 \\
Fundic gland & & 11 & 14 & \\
\hline
\end{tabular}

\section{Size}

Polyps were $0.3-4.0 \mathrm{~cm}$ in size. The Table 3 shows the relationship between polyp type and size. The most number are less than $1 \mathrm{~cm}$.

TABLE 3. Relationship between polyp type and size. The values indicate number of cases and percentage

\begin{tabular}{lccc}
\hline \multirow{2}{*}{ Polyp type } & \multicolumn{3}{c}{ Size } \\
\cline { 2 - 4 } & $<1 \mathrm{~cm}$ & $1-2 \mathrm{~cm}$ & $>2 \mathrm{~cm}$ \\
\hline Hyperplastic & $66(60,5 \%)$ & $20(18,3 \%)$ & $23(21,2 \%)$ \\
Adenomatous & $14(73,6 \%)$ & $3(15,8 \%)$ & $2(10,6 \%)$ \\
Fundic gland & $18(72 \%)$ & $7(28 \%)$ & - \\
\hline
\end{tabular}

\section{Yamada's classification}

Polyps were classified macroscopically according to Yamada's classification $^{(20)}$. Yamada type I polyps are elevated, with an indistinct border (Figure 1). Type II polyps are elevated with a distinct border at the base but no notch. Type III polyps are elevated, but no peduncle (Figure 2). Type IV polyps are pedunculated and elevated (Figure 3 ). The Table 4 shows the relationship between Yamada's classification and polyp size.

\section{Histopathological findings}

Histopathologically, only one HP presented focal carcinoma. This polyp was $4 \mathrm{~cm}$ in size and was located near the anastomosis in a patient with Billroth II gastrectomy. One AP (5.2\%) was tubulopapillary, and the others $(94.8 \%)$ were tubular. Three AP had dysplastic foci, which were low grade in two and moderate grade in one. Focal cancer was found in two AP, both of which
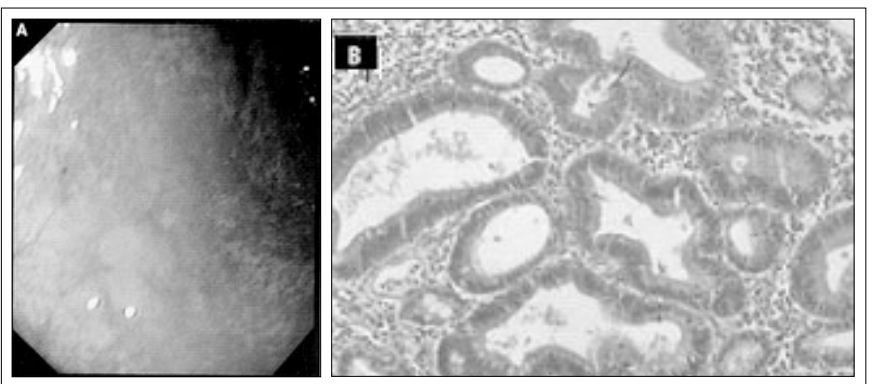

FIGURE 1. Adenomatous type I polyp in the gastric body. Bounded elevation of white tonality and adjacent mucosa with accentuation of the vascular pattern (atrophic mucosa) (A). Histopathological findings shows focal cancer (differentiated adenocarcinoma) into the mucosa (B). $\mathrm{X} 40, \mathrm{X} 10$
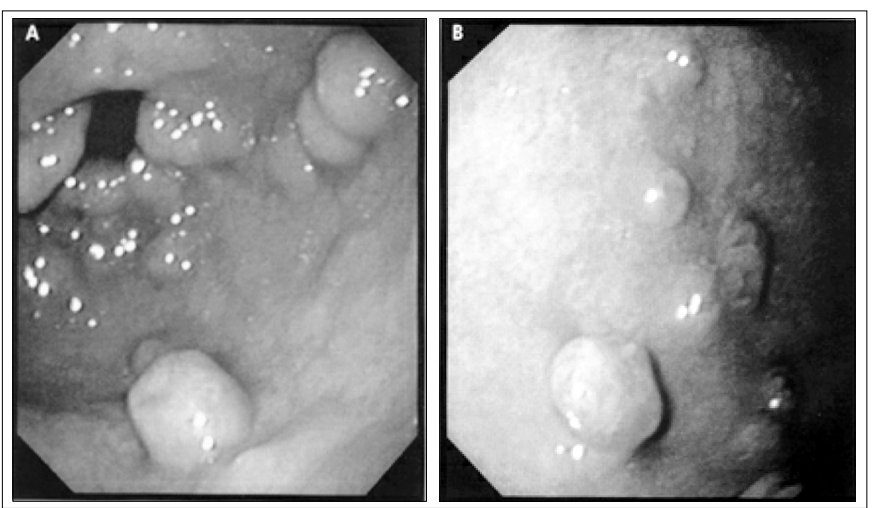

FIGURE 2. Gastric polyposis. Hyperplastic type III polyps in the antrum (A) and in the gastric body (B)
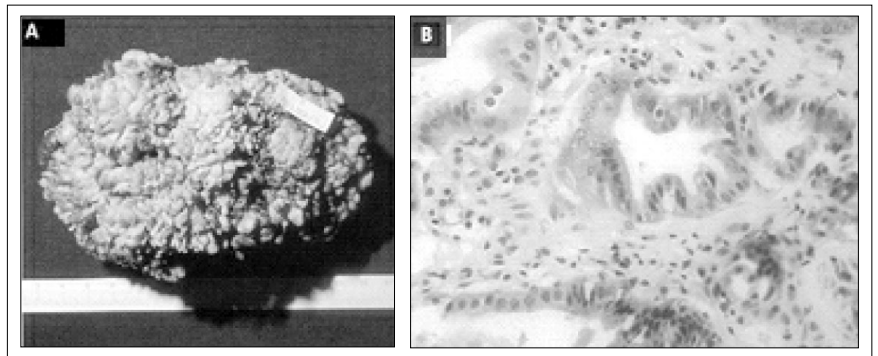

FIGURE 3. Adenomatous type IV polyp in the gastric body, with great proportions and multilobular, with villous aspect (A). Histopathological findings shows focal cancer (adenocarcinoma) (B). X200

TABLE 4. Relationship between Yamada's classification and polyp size. The values indicate number of cases

\begin{tabular}{lccc}
\hline \multirow{2}{*}{ Polyp size } & \multicolumn{3}{c}{ Yamada's classification } \\
\cline { 2 - 4 } & I and II & III & IV \\
\hline$<1 \mathrm{~cm}$ & 51 & 8 & 1 \\
$1-2 \mathrm{~cm}$ & 23 & 27 & 7 \\
$>2 \mathrm{~cm}$ & 3 & 7 & 11 \\
\hline
\end{tabular}


were differentiated adenocarcinomas (Figures 1 and 3). FGP showed no dysplasias and no carcinomas.

\section{Treatment}

Yamada I and II gastric polyps $\geq 1 \mathrm{~cm}$ in diameter, as well as Yamada III and IV polyps, were removed by snare polypectomy. All AP were also removed by snare polypectomy. Gastric polyps with a diameter $<1 \mathrm{~cm}$ were biopsied with forceps for histological diagnosis before deciding on how they should be managed. HP $<1 \mathrm{~cm}$ in diameter was recommended for followup by periodic endoscopy.

\section{DISCUSSION}

Gastric polyps are small lesions, which are asymptomatic in most cases and are generally discovered inadvertently during endoscopic examination. Our incidence of $0.6 \%$ differed from the incidence of approximately $2 \%$ reported by $\mathrm{MING}^{(10)}$. $\mathrm{HP}$ are the most frequent histological type of gastric polyps reported in the literature and accounted for $71.3 \%$ of the cases in our series, followed by FGP $(16.3 \%)$ and AP $(12.4 \%)^{(12,19)}$.

The clinical findings associated with gastric polyps depend on the polyp size and location ${ }^{(3)}$. Some patients may present with no specific digestive symptom. Erosion or ulceration of the polyp surface may cause occult bleeding and anemia, and upper gastrointestinal bleeding may occur if there are large lesions. A large polyp with the potential to pass from the antrum to the pylorus can cause intermittent obstruction. Symptoms such as pain, nausea and vomiting were frequent in most patients and could not be attributed solely to the polyp found, since there were frequently other endoscopic alterations implying other gastroenterological diseases ${ }^{(18)}$

The gastric polyp may be located anywhere in the gastric mucosa. In our study, HP were more frequent in the antrum, followed by the body, fundus and gastroenteroanastomosis. These polyps were single in most cases, but in $8.2 \%$ they occurred as multiple polyps. AP were present in the antrum in 50\% of the cases, with a lower frequency in the body, fundus and anastomosis. In our series, FGP were multiple in most cases, with a diameter of $<1 \mathrm{~cm}$ and were most frequent in the fundus. Our observations confirmed previous reports that FGP occurred within the body and fundus ${ }^{(1,3,7,15)}$. Histological examination of HP in our series showed that only $(0.9 \%)$ of the 109 cases had focal carcinoma in the form of a large, pedunculated polyp $4 \mathrm{~cm}$ in diameter located in the gastroenteroanastomosis resulting from Billroth II gastrectomy. This was the only HP with a histological alteration.

The risk of developing a carcinoma in HP is rare and these polyps are not considered pre-cancerous lesions. Previous reports have shown that the risk of focal adenocarcinoma within HP is less than $1 \%{ }^{(12)}$, but occasionally greater than $1 \%{ }^{(6)}$. DAIBO et al. ${ }^{(2)}$ suggested these polyps grow large and become semi-pedunculated or pedunculated, with the appearence of dysplastic foci and followed by the cancerous lesion. This author also suggested that HP could become malignant, although this was uncommon. The process of malignant transformation is poorly understood and few investigations have examined its histogenesis ${ }^{(4,5,6,16)}$.
Histopathological analysis of the 19 AP in our series showed that only one was tubulopapillary $(5.2 \%)$, with the others being tubular (94.8\%). High dysplastic foci were observed in four AP (21\%). The tubulopapillary adenoma showed moderate dysplasia. In three tubular AP, two had low dysplasia and only one had high grade dysplastic foci. Two AP (10.5\%) $2 \mathrm{~cm}$ and $1.5 \mathrm{~cm}$ in diameter respectively (Fig. 3 and 4 ) had focal carcinoma. AP are infrequent polyp lesions, accounting for 5\%-10\% of all gastric polyps ${ }^{(16)}$. Their histopathological type may be tubular or papillary and, if these two types coexist in the same polyp, they may become tubulopapillary.

Papillary and tubulopapillary AP have a greater chance of becoming malignant. NAKAMURA and NAKANO ${ }^{(12)}$ reported cancer in $33 \%$ of cases with AP. This association has been related directly to the size of the AP, with $24 \%$ of polyps being $\geq 2 \mathrm{~cm}$ in diameter. In our series, one AP with malignant changes was $2 \mathrm{~cm}$ in diameter, semi-pedunculated, and had a central depression. In contrast, another polyp which was $1.5 \mathrm{~cm}$ in diameter showed no sign of malignancy.

Histopathological analysis of FGP revealed no alterations, and there was no association between FGP and adenocarcinoma of the stomach. Besides, the association between FGP and patients taking longstanding proton-pump inhibitors were not recorded.

BURT $^{(1)}$ studied patients with FGP and emphasizes that they may be a trivial finding or evidence of a significant underlying inherited polyposis syndrome and colonoscopy shoud be done.

Complete polypectomy of all epithelial gastric polyps larger than $5 \mathrm{~mm}$ is recommended by the experienced endoscopists, after thorough individualised risk-benefit analysis ${ }^{(8,11)}$. Large series of polypectomies published in 21 st century in different countries, showed diverse incidents of histopathological findings. SIVELLI et al. ${ }^{(18)}$ studied 164 gastric polyps removed and found $44,5 \%$ of HP, $16,4 \%$ of AP and $0,6 \%$ of malignant lesions in AP, emphasizing that there is a relationship between histological type, neoplastic change and the size of the polyps. HNIZDIL et al. ${ }^{(7)}$ analysed the polypectomies performed in a total of 10,260 digestive tract endoscopies (28 polyps) and related $67,8 \%$ of HP, $21,5 \%$ of FGP and $10,7 \%$ of AP. MACENLLE-GARCIA et al. ${ }^{(9)}$ analysed the polypectomies in a series of 5,314 upper endoscopies (64 polyps) and related $37,5 \%$ of HP, $12,5 \%$ of AP and $2 \%$ of malignant lesions. PALACIOS-SALAS et al. ${ }^{(14)}$ related $75 \%$ of HP, $16,2 \%$ of AP and $5,9 \%$ of FGP in 6,603 upper endoscopies (68 polyps).

The management of small or asymptomatic gastric polyps remains controversial ${ }^{(5,7)}$. In our series, all Yamada III and Yamada IV gastric polyps were removed by endoscopic snare polypectomy. For Yamada I and Yamada II gastric polyps $<1 \mathrm{~cm}$, we obtained biopsies for histopathological diagnosis before deciding on their management. Hyperplastic gastric polyps $<1 \mathrm{~cm}$ in diameter (Yamada I and II) were not removed by endoscopic snare polypectomy but were followed-up by periodic endoscopies. The other HP were removed by endoscopic snare polypectomy. All AP were removed by endoscopic snare polypectomy, whereas FGP $<1 \mathrm{~cm}$ in diameter (Yamada I and II) were followed by endoscopy. 
In conclusion, gastric epithelial polyps are infrequent and most of them measure less than $1 \mathrm{~cm}$. The digestive endoscopy is the safest and efficient method for the diagnosis of the gastric polyps, that in most of the patients does not show characteristic symptoms. The histopathological definition is not possible to the endoscopic glance being needed the pathologist's aid, once the conduct to be adopted will depend on the result of the biopsy.

\section{ACKNOWLEDGMENTS}

The authors thank Drs. Nelson Ary Brandalise, Ciro Garcia Montes, Fabio Guerrazzi, Antonio F. Carvalho Jr., José Olympio Meirelles dos Santos, Jazon R. Souza Almeida, Luiz Roberto Lopes and Rosângela Deliza of the Gastrocenter Endoscopy Unit and Department of Pathology for providing the pictures and for their help in collecting and studying the biopsy material.

Morais DJ, Yamanaka A, Zeitune, JMR, Andreollo NA. Pólipos gástricos: análise retrospectiva de 26000 endoscopias digestivas. Arq Gastroenterol. 2007;44(1):14-7.

RESUMO - Racional - Os pólipos gástricos são pequenas lesões gástricas, assintomáticos na maioria dos casos, e são diagnosticados por acaso durante a endoscopia digestiva alta. Objetivos - Avaliar retrospectivamente as características e freqüência dos pólipos gástricos, oriundos da mucosa gástrica em uma casuística extensa de endoscopias digestivas. Métodos - Cento e cinqüenta e três doentes em uma casuística de 26.000 endoscopias digestivas altas realizadas durante 5 anos, sendo que cada doente realizou apenas um exame, foram analisados quanto às características histopatológicas, classificação de Yamada, localização, tamanho e tratamento. Todos os casos tinham pelo menos um pólipo gástrico, confirmado pelo exame histopatológico de biopsia endoscópica. Resultados - Os pólipos foram classificados como hiperplásicos, adenomatosos e de glândulas fúndicas. A maioria deles era menor que 1 cm (pólipos hiperplásicos - 60,5\%; pólipos adenomatosos - 73,6\%; pólipos de glândulas fúndicas - 72\%). Os pólipos hiperplásicos foram os mais freqüentes e diagnosticados em $71,3 \%$ dos casos, enquanto os de glândulas fúndicas somaram 16,3\% e os adenomatosos foram 12,4\%. Os pólipos hiperplásicos e os adenomatosos, na maioria das vezes, foram únicos, enquanto os de glândulas fúndicas tenderam a ser múltiplos. Carcinoma foram detectados em um pólipo hiperplásico (0,9\%) e em dois adenomatosos (10,5\%). Focos de displasia de alto grau foram encontrados em quatro pólipos adenomatosos (21\%). Conclusões - A endoscopia digestiva é o método mais seguro e eficiente para o diagnóstico dos pólipos gástricos, que na maioria dos doentes não apresenta sintomas característicos. A definição histopatológica não é possível ao olhar endoscópico, necessitando-se do auxílio do patologista, uma vez que do resultado da biopsia dependerá a conduta a ser adotada.

DESCRITORES - Gastropatias. Pólipos, cirurgia. Endoscopia gastrointestinal.

\section{REFERENCES}

1. Burt RW. Gastric fundic gland polyps. Gastroenterology. 2003;125:1462-9.

2. Daibo M, Itabashi M, Hirota T. Malignant transformation of gastric hyperplastic polyp. Am J Gastroenterol. 1987;82:1016-25.

3. Deppish LM, Rona VT. Gastric epithelial polyps: a 10-year study. J Clin Gastroenterol. 1989;11:10-5.

4. Di Giulio E, Lahner E, Micheletti A, Milione M, D’Ambra G, Bordi C, Delle Fave $\mathrm{G}$, Annibale B. Occurrence and risk factors for benign epithelial gastric polyps in atrophic body gastritis on diagnosis and follow-up. Aliment Pharmacol Ther. 2005;21:567-567.

5. Ginsberg GG, Firas HAK, Fleischer DE, Reilly HF, Benjamin SB. Gastric polyps relationship of size and histology to cancer risk. Am J Gastroenterol. 1995;91:714-7.

6. Hattori T. Morphological range of hyperplastic polyps of the stomach. J Clin Pathol. 1985;38:622-30

7. Hnizdil L, Piskac P, Dvorak M. Endoscopic gastric polypectomy - personal experience. Rozhl Chir. 2002;81:324-6.

8. Hughes R. Gastric polyps and polypectomy: rational, technique and complications. Gastrointest Endosc. 1984;30:101-2.

9. Macenlle-Garcia R, Bassante-Flores LA, Fernandez-Seara J. Gastric epithelial polyps. A retrospectrive study 1995-2000. Rev Clin Esp. 2003;203: 368-72.

10. Ming SC. Malignant potential of epithelial polyps of stomach. In: Ming SC, editor Precursors of gastric cancer. New York: Praeger; 1984. p.219.
11. Muehldorfer SM, Stolte M, Martus P, Hahn EG, Ell C. Diagnostic accuracy of forceps biopsy versus polypectomy for gastric polyps: a prospective multicentre study. Gut. 2002;50:465-70.

12. Nakamura T, Nakano G. Histopathological classification and malignant chance in gastric polyps. J Clin Pathol. 1985;38:754-64.

13. Oota K. Histological typing of gastric and oesophageal tumors. In: WHO, editor. International classification of tumors, 18. Genève: WHO; 1977. p.37.

14. Palacios-Salas F, Frisancho-Velarde O, Palomino-Portilla E. Gastric polyps and histological changes in surrounding mucosa. Rev Gastroenterol Peru. 2003;23:245-53.

15. Randall GM. Endoscopic diagnosis of gastric neoplasm. Gastrointest Endosc Clin North Am. 1992;2:469-93.

16. Robbins SL. Tumors of the stomach. In: Robbins SL, editor. Pathological basis of disease. Boston: W.B. Saunders; 1995. p.161.

17. Seifert E, Gail K, Weismuller J. Gastric polypectomy. Endoscopy. 1985;15:8-11.

18. Sivelli R, Del Rio P, Bonati L, Sianesi M. Gastric polyps: a clinical contribution. Chir Ital. 2002;54:37-40

19. Snover D. Benign epithelial polyps of the stomach. Pathol Ann. 1985;20(part I):303-29.

20. Yamada T, Ichikawa H. X-ray diagnosis of elevated lesions of the stomach. Radiology. 1974;110:79-83.

Recebido em 6/2//2006. Aprovado em 10/8/2006 